\title{
A VÍZMINŐSÉG BIZTONSÁG MODERNKORI KIHÍVÁSAI
}

\author{
MODERN CHALLENGES OF WATER QUALITY SAFETY
}

\author{
CSŐsZ László \\ (ORCID: 0000-0003-1662-5139) \\ csosz.laszlo@uni-nke.hu
}

\begin{abstract}
Absztrakt
A szennyvíztisztítás hatékonysága mára elérte a határát, amennyiben a szennyvizekben megtalálható összes kritikus anyag eltávolítását nézzük. Egyre összetettebb eljárásokra van szükség, amelyek növelik a költségeket, ráadásul egyes tisztítási folyamatokhoz is bizonyos vegyi anyagok használata szükséges, ami nem egyszer extra terhelést jelent a vizeink számára. Ami miatt néha nem hogy tiszta vizet kapunk eredményképpen, hanem a tisztítási folyamat végén - még ha egyéb módon is -, de szennyezettebbet. Ezen felül komoly problémát jelentenek az éghajlatváltozás, illetve az annak következményeként fellépő szélsőségek. A csapadékintenzitás változása, az el-és lefolyási nehézségek következményeként fellépö bemosódási-vízminőségi változások mind veszélyt jelentenek felszíni és felszín alatti vizeinkre.

Jelen cikk azon folyamatokat célozza bemutatni, amelyek új kihívásként jelentkeznek a vízminőség biztositása érdekében, illetve rámutat egyes olyan kihívásokra is, amelyek ugyan már régebben is azonositott problémakört jelentettek, azonban az éghajlatváltozás hatásainak következményeként újfent elötérbe kerültek, súlyozottabban jelennek meg.
\end{abstract}

Kulcsszavak: vízbázisok szennyezése, éghajlatváltozás, mikroszennyezők, új

\begin{abstract}
The efficiency of waste water cleaning reached its limit by today, considering the removal of every critical material to be found in waste waters. Always more complex procedures are required, which increase the costs, additionally certain chemicals shall be used for individual cleaning processes, which means an extra stress for our waters. Due to which one does not receive clean water as result, but at the end of the cleaning process - even otherwise - more contaminated. In addition, climate change and the extremities resulting therefrom mean a serious problem. The change of rainwater intensity, the leaching water quality changes resulting as consequence of outflow and run-off endanger our surface and subsurface waters. This article aims at demonstrating processes, which arise as new challenge for the assurance of water quality and points out some challenges respectively, which formerly meant an identified issue, however as consequence of the effects of climate change came to the front again and appear in a more weighted manner.
\end{abstract}

Keywords: contamination of water bases, climate change, micro contaminants, new challenges 


\section{BEVEZETÉS}

A vegyi anyagok nélkülözhetetlenek a modern életvitel számára. Az élet sok területén könnyítik meg az életünket, biztosítják a jólétet, az egészséget és a megfelelő életminőséget. Ugyanakkor ezek a vegyi anyagok problémát is okoznak, mert bekerülnek a vízkörforgásba, és ezáltal visszakerülnek az élelmiszerláncba. Az, hogy felszíni és felszín alatti vízbázisaink az elmúlt fél évszázadban egyre nagyobb szennyezőanyag terhelésnek vannak kitéve, illetve a globális felmelegedési folyamatok mind mennyiségi, mind minőségi szinten erőteljesen hatnak rájuk, már a laikusok számára is nyilvánvalóvá vált. A védelemmel foglalkozó szakemberek, kutatók különféle módszerekkel, worst case - best case szcenáriókkal próbálnak előzetes jóslatokat felállítani arra vonatkozólag, hogy milyen mértékben fogy a vizek mennyisége és romlik azok minősége.

Az Európai Unió, ahogy sok más terület esetében, úgy a vízszennyezések terén is a megelözésre fekteti a hangsúlyt. Dr. Kümmerer [1] szerint a jövőben azonban sokkal nagyobb figyelmet kell fordítani a szennyező anyagok vízbe kerülésének a korai szakaszban történő csökkentésére, máskülönben az egyébként a hatékony szennyvízkezelés már nem biztosítható. Bár ez EU országai a szennyvizek gyüjtése és kezelése tekintetben relatív problémamentes területnek tekinthetőek, de a világ országainak $80 \%$-ban nem is léteznek szennyvíztisztító telepek, ezáltal a vizek szennyezése továbbra is napi szinten jelent gondot. [2]

Vízszennyezések esetében megkülönböztetünk közvetlen és közvetett szennyező forrásokat. A közvetlen szennyezés esetében bármely szennyező anyag közvetlen kerül bevitelre, például a szennyvíztisztítókból, gyárakból vagy a települési szennyvízből. Közvetett vagy akár diffúz terhelések valamely közvetítő közegen kerülnek bele a vízbázisokba, például a talaj és a talajvíz elszennyeződése által (mütrágyákból, peszticidekből a mezőgazdasági használatú földterületekről), közúti szennyeződések bemosódásából (gumiabroncsok kopása, útszóró só, kőolajszármazékok), illegálisan elhelyezett szemétből, stb. (Jelen cikk a tartós szennyezésekkel foglalkozik, a havaria jellegü szennyezéseket nem tárgyalja.)

Jóllehet az egyes szennyeződések súlyos és akut következményeinek nagy figyelmet szentelnek, azok hosszú távú értékelése viszonylag újkeletü. Amennyiben a szennyezőforrásokat tekintjük, azok megoszlásának körülbelül felét teszik ki a közvetlen kibocsátásúak, a másik felét pedig a diffúz forrásoknak köszönhetik, de a mérleg az egyes szennyező anyagoktól és vizektől függően egyedileg különbözik. [3]

A közvetett vízszennyezést elsősorban a kibocsátás korlátozásával kell és lehet csökkenteni, de ide sorolhatóak az olyan beavatkozások is, mint a földhasználati módok megváltoztatása, korlátozások. A vízbázisok védelme érdekében speciális vízvédelmi területek kijelölése már megtörtént, azonban az újonnan felmerülő kihívások szigorúbb feltételeket követelnek.

Annak érdekében, hogy vízhasználatunkat fenntarthatónak minősítsük, ezáltal a jövő nemzedékei számára is biztosított legyen a kellő mennyiségü és minőségü ivóvíz, már a keletkezésénél kell megszüntetni a lehetséges vízszennyezést. Mindenekelőtt a prioritással kezelendő veszélyes anyagok ${ }^{1}$, mint a nehézfémek, növényvédő szerek és ipari vegyszerek által történő szennyezéseket kellene kiszorítani, ráadásul lehetőség szerint egy generációnyi vízkörforgás ideje alatt. ${ }^{2}$ Ezen anyagok listáját folyamatosan felülvizsgálják és kiegészítik. A jelenlegi legproblémásabb területet az úgynevezett nyomelemek, azaz a mikroszennyező anyagok jelentik. A nyomelemek közé tartoznak különösen a humángyógyszerek hatóanyagai és azok bomlástermékei.

\footnotetext{
${ }^{1}$ Ezek listája az EU-ban összeállításra került.

${ }^{2}$ A tengervédelem céljait is egy ilyen rövidtávú beavatkozás szolgálja.
} 


\section{GLOBÁLIS FELMELEGEDÉS HATÁSAI}

Az IPCC (Intergovernmental Panel on Climate Change - az ENSZ Éghajlatváltozási Kormányközi Testülete) korábbi jelentései is már sötét képet festettek a Föld klimatikus viszonyainak tekintetében általánosan is, de a vízbázisokkal kapcsolatban is. Azonban a 2018as soron kívül kiadott jelentés (Special Report 1.5) még rosszabb szcenáriókból indultak ki, és a 2016. évi 5. jelentéssel szemben prognosztizált 2 Celsius-fokos lehetséges hőmérsékletnövekedést már lejjebb szállították, és felhívták a figyelmet arra, hogy azt maximálisan 1,5 fokon kell tartani ahhoz, hogy ne következzenek be visszafordíthatatlan folyamatok. A jelentés szerint [4]:

- legkésőbb 2020-ban tetőznie kellene a szén-dioxid-kibocsátásnak (ami nemrég döntött rekordot);

- a 2030-ig hátralévő években a 2010-es szinthez képest 45 százalékkal kell csökkenteni az üvegházhatású gázok kibocsátását;

- 2050-ig pedig 100 százalékos csökkenést (tehát nettó nullához közeli értéket) kellene elérni. Jelenleg az elektromos energia 40 százalékát még mindig szénerőművek termelik, 2050-re ennek 1-7 százalékra kellene csökkennie;

- a megújuló forrásból származó (pl. nap- és szél-) energia jelenleg 20 százalékos részesedésének a század közepére 67 százalékra kellene nőnie az elektromosenergiamixben.

A vízkészletek mennyiségét és minőségét az éghajlat és annak változása befolyásolja a víz körforgása által, a vízbázisok érzékenyen reagálnak rá. [5] A hidrológiai jellemzők térben és időben is követik az éghajlatváltozást, az általa generált hatásokat, a csapadék és a párolgás változásait. Hazánkban kiemelt szerepet játszik a vizek „életében” az évszakok változása, így ugyanilyen kiemelt szerepet kapnak az éghajlatváltozás okozta hatások is. A levegö felmelegedése a víz hőmérsékletének melegedésével megváltoztatja a vízi élővilágot, a vízi világ összetétele pedig hatással van a víz minőségére. Az alacsony áramlási tényezők rontják a víz öntisztulását, a víz minőségét, ezáltal fokozva az eutrofizációt, ami mérgező algák virágzását idézi elö önmagában is.

Jó néhány, tényszerü adatokkal alátámasztott tudományos felismerés is rámutat arra, milyen tényleges, számszerüleg kimutatható napi kockázati tényezőt is jelent a szélsőséges időjárási jelenségek gyakoribbá válása. A lecsökkent csapadék mennyisége kimutathatóan intenzívebb mintázatot eredményezve nem egyszerüen csökkenti a víz potenciális kihasználhatóságát, hanem növeli az áradások kockázatát, a velük kapcsolatos káresemények számát és kiterjedését is. [6]

Az éghajlatváltozás egyik következményeként megnövekszik azon nagyintenzitású csapadékesemények száma, amelyek szintén külön terhelést jelenthetnek a környezetre. A hirtelen fellépő (ár)vizek kimoshatják tisztítatlanul a még kezeletlen szennyvizet, amely kijutva további veszélyeket hordoz magában. Amennyiben a hazai vízi közmüvagyon állapotát figyelembe vesszük, a helyzetet súlyosbítja az a tény is, hogy sok esetben nincs külön esővízelvezető, záportározó kialakítva, és még egy jól karbantartott csőhálózat terhelésekor is, szélsőséges, özönvízszerü esőzésekkor a rendszer telítődésének hatására komoly mennyiségü szennyezőanyag kerülhet ki a természetbe, ahol nem csak a felszíni vizeket, de beszivárgással a felszín alattiakat is veszélyezteti. ${ }^{3}$

\footnotetext{
3 Természetesen szélsőséges időjárási esemény és egyéb katasztrófa hiányában is bemoshat csapadék fedett felületekről szennyezéseket bármelyik vízbázisba, amennyiben a megfelelő elvezetés nélkül egyenesen a talajra vagy a vizekbe kerül.
} 
A WWF 2018-as jelentésében arra a figyelmet, hogy folyóvizeinkre azért is jobban kellene vigyáznunk, mert egy „egészséges” folyók hozzájárul a természeti katasztrófák mérsékléséhez. Ahhoz, hogy betöltsék folyóvizeink funkcióikat, azok primer és szekunder tulajdonságaira kevéssé „szolgáltatásként” kellene tekintenünk, illetve a vizeket nem puszta víz- és energiaforrásként kell felfognunk. A jelentést összeállító kutatócsoport megvizsgálta a világ GDP-jét a tekintetben is, mennyire kötődnek a magas kockázatú vízgyüjtő területekhez. Mivel ilyen szinten a világ országainak majd $20 \%$-a érintett, felhívják arra is a figyelmet, hogy a fenntarthatósági kérdéskör szem elött tartásának érdekében át kell alakítani a folyók kezelésére irányuló nézeteket. [7] Amennyiben a hazai természetes vizeket vizsgáljuk meg, azok elsőlegesen a lakosság vízigényét szolgálják ki (a felszíni vizekből a lerakott kavicsréteg által megszürt kiváló állapotú és jó minőségü parti szürésű vizek által). Napjainkban az ivóvíz közel 40\%-a származik parti szürésü forrásból, távlati szinten ennek az aránynak a jelentős növekedésével számolnak. Ugyanakkor a folyószabályozás következtében az árterek állapota jelentősen átalakult, amire az éghajlatváltozás nyomán fellépő szárazodás súlyos többlet terhet ró, ezek jellemzően nem kapnak kellő vízmennyiséget, így az élőhelyek egyre szárazabbak, a vízpartok regenerálódó képessége csökken. De hasonlóan hatással vannak a nagy áramlási események - a vízfolyás sebessége, a vízszint változása miatti parterózió - is a vízbázisokra. [8]

\section{KÉMIAI EREDETÜ SZENNYEZŐ ANYAGOK}

Az elmúlt időszakban mind sürübben láttak napvilágot olyan vizsgálatok, amelyek az európai felszíni élővizekben gyógyszermaradványokat tudtak kimutatni. A rendszeres és szabályos szennyvíztisztítási folyamatok nem tudják eltávolítani ezeket a mikrószennyezőket. Jóllehet amióta felismerték ezek veszélyét, egyre több olyan pótlólagos technikai elemet tesznek be szennyvíztisztítás folyamatába, amelyek kifejezetten ezen nyomelemek eltávolítását célozzák. A mikrószennyező anyagok, gyógyszermaradványok száma igen magasra tehetö, csak az EUban több, mint 2000 engedélyezett hatóanyag található meg, ami az emberi használat után vizeinkbe kerül, és célzott vizsgálatokat végezve, azok ki is mutathatóak azokban.

Ezekkel az anyagokkal kapcsolatosan az is problémát jelent, hogy bár egyre több olyan technológiát fejlesztenek ki, ami ezek eltávolítását célozza, sokszor a szennyező anyag nem kerül eltávolításra, hanem egyéb vegyületekké alakulnak, a tisztítási technológiák hatására, illetve a tisztítást szolgáló kémiai anyagokkal együtt más anyagokat képeznek, amelyek hasonlóan károsak, esetlegesen még károsabbak a környezet számára, mint a kiinduló anyag. [9]

Az uniós alapelvek, a katasztrófa-, a kritikus infrastruktúraelemek védelmét szolgáló jogi szabályozás következtében kialakult rendszer a megelözésre helyezi a hangsúlyt. Ennek a lényege, hogy a kritikusnak és veszélyesnek ítélt vegyi anyagok ne is kerüljenek bele vizeinkbe.

Azonban az új típusú szennyezőanyagok új típusú tisztítási eljárásokat követelnek, amelyek technikai feltételei nem mindig megoldottak. Kümmerer et al. felhívja a figyelmet arra, hogy az lenne elsődlegesen kívánatos elméleti síkon, hogy ezen anyagok már a tisztítandó szennyvizet, és ezáltal szennyvíztisztítókat se érjék el, hanem még a tisztítási folyamatok előtt ártalmatlanná kellene válniuk, különben a szennyvízkezelés szinte megoldhatatlan nehézségekkel szembesül. Mivel modern életmódunk vegyianyag használata pillanatnyilag nem teszi lehetővé ezt a megoldást, tehát az egyes mikrószennyezők, gyógyszermaradványok szennyvízbe való bekerülése elkerülhetetlen folyamat, ezeket az anyagokat, azok életciklusát a kezdetektől úgy kell megtervezni, hogy ne károsítsák a környezetet, hiszen egy esetleges környezetszennyezés jóval könnyebben leküzdhető a forrásnál, mint hozzájuk kapcsolódva egyre több és drágább tisztítási folyamatokat kifejleszteni.

Problémát okoz az is, hogy a méretében és kvalitásaiban komolyabbnak tekinthető szennyvíztisztító telepek nagyobb beruházásnak minősülnek, átlagosan legalább 30-50 évre 
építik öket. Ezzel szemben különféle okok miatt a jogszabályi környezet akár ennek tizede alatt átalakul (pl. tisztított vizekre vonatkozó határértékek előírásai), de fontosabb tényező, hogy a szennyvíz minőségi és mennyiségi oldalon is megváltozik. A kialakított meglévő, a telepeken alkalmazott technológia adaptálása a változásokhoz kérdéses. Amennyiben a tisztításra alkalmazott technológia nem adaptálható a beérkező nyers szennyvízhez, illetve azokhoz a körülményekhez és követelményekhez, amelyeket a felszíni befogadó vízbázis határozott meg, akkor ez állandó problémákhoz vezet. Gondot sokszor az is okoz, ha a tervezés során csak szimulációs modelleket alkalmaznak, nem megfelelő adatfelvételi eljárás szerint. Amennyiben egy tisztítási technológia koncepcionálisan nem megfelelö, ráadásul nem képes alkalmazkodni a nyers szennyvízminőséghez, annak változékonyságához, a kijövő tisztított víz minősége sem lesz megfelelö a határétékek tekintetében (amelyet a telepek adatai is bizonyítanak, legtöbbször az össznitrogén határok, ammónium, lebegőanyagok számadatainak tükrében). Az innovációs változtatások elsődlegesen az egyes moduljaiban és/funkcióiban adaptációképes technológiai fejlesztéseket igényelnek. Ugyanilyen technológiai kérdés a mikroszennyezők, gyógyszer- és hormonmaradványok kivonásának lehetősége [10]

Kisebb tisztítóművek esetében a szennyvíziszap kezelési gyakorlata is változtatást igényel. A keletkezett mennyiség 20-25\%-a még mindig lerakókban végzi, ami a több mint $5 \%$-os határértéket meghaladó szervesanyagtartalma miatt EU-s jogszabályokkal is ellenkezik, tehát önmagában sem fenntartható, de a felszíni beszivárgás veszélyezteti az vízbázisokat. [11]

\section{MEGOLDÁSI LEHETŐSÉGEK}

A gyógyszerekből származó szennyezések tekintetében komoly sikereket érhetnének el a megelőzés terén. Mindezidáig nem fordítottak figyelmet az egyes gyógyszerek és hatóanyagaiknak a környezetre gyakorolt hatásának vizsgálatára, azok alárendelt szempontok voltak. Mivel azonban ezek a víz körforgásának köszönhetően az emberi egészséget befolyásolják, ezek vizsgálata, valamint az eliminálására tett lépések egyre inkább előtérbe kerülnek.

A megelőzés elvének teljesüléséhez a szakemberek egyik alappillérnek a felhasználói hozzáállás megváltoztatását is tekintik. Hiszen nem kell minden esetben valamilyen gyógyszerhez nyúlni, vagy ha feltétlen szükség van a gyógyszerek használatára, az adagolást minden esetben meg kell fontolni, hiszen a szervezet sokszor a bevett gyógyszerek csak elenyésző hányadát tudják hasznosítani, a többi a vizelettel távozik a szervezetünkböl. Ugyanilyen fontos, hogy a fel nem használt, esetleg lejárt szavatosságú gyógyszereket soha ne dobjuk szemétbe, vagy húzzuk le a vécén, hiszen a gyógyszertárakba visszavíve szakszerüen kerülnek megsemmisítésre.

Természetesen a megelőzés azt is jelenti, hogy az ipar lehetőség szerint olyan irányba kellene, hogy eltolódjon, hogy minél kevesebb vegyi anyagot használjon fel, illetve, hogy a lebontható anyagok számát növeljék meg. Egyes ipari folyamatoknál már figyelnek a keletkező, vegyi anyagokkal terhelt szennyvizek megfelelő (elö)kezelésére, az esetleges újrahasznosítási lehetőségekre. A modernebb (gyártás)technológiai berendezések már eleve víztakarékosabbak, igyekeznek kevesebb szennyezéssel terhelni a technológiai vizet, összességében elmondható, hogy egyes ipari szennyvizeket tisztítás után vissza lehet forgatni a rendszerbe, vagy bizonyos iparágak szennyvizei egyéb iparágak gyártási folyamatánál hasznosíthatók (pl. kőszéniparból származó szennyvíz és szennyvíziszap a brikettgyártásnál felhasználható). Egyes gyártási folyamatok szennyvizeiből a sókat, az egyes festékanyagokat vissza lehet nyerni, újra lehet hasznosítani. Ilyenek keletkeznek például a textíliák színezésénél. A kozmetikai iparban széles körben alkalmazott és a környezetben komoly problémákat okozó mikromüanyagok elhagyhatóak, helyettesíthetőek egyéb nem veszélyes anyagokkal. Bizonyos élelmiszeripari ágazatok keletkező és kezelt szennyvizeit mezögazdasági öntözésre, de akár halastavak 
táplálására is fel lehet használni, és hütő- vagy fütővízként való alkalmazásuk szintén lehetséges.

A szennyvizek tisztítási problémáinak elkerüléséhez jelenleg egyre inkább arra tolódik el a kutatás, és egyre ígéretesebb megközelítéssel keresik a megoldásokat, hogy még a gyártási folyamatok előtt elemezik a gyártási folyamatokban és a termékben a vegyi anyagok müködési elvét, és keresik azon alternatívákat, amelyek ugyanazon célt szolgálják, de nem kémiai alapúak. A háztartásokban a megelőzés elve alapján egyértelmü, hogy el kell érni azt is, hogy az ott keletkező szennyvizet is külön gyüjtsék és kezeljék a könnyebb és hatékonyabb tisztítás érdekében.

Mivel vegyi anyagokra és gyógyszerekre továbbra is szüksége lesz az emberiségnek, a komoly problémák felmerülésének elkerülése érdekében érdemes a „benign by design” elvét követni. A már az 1990-es években, a „green chemistry” irányába elmozduló kutatók és tudósok által megfogalmazott igény alapján, már az egyes kémiai anyagok, formulák kialakításakor olyan irányba kell(ene) elmozdulni, hogy azok a környezetet kevéssé károsítsák, illetve teljességgel lebonthatóak legyenek. Ehhez elemezni kell az egyes vegyi anyagoknak a gyártási folyamatban és a termékben való müködését, és olyan nem kémiai alternatívákat kell keresni, amelyek ugyanazt a célt szolgálják. Az úgynevezett ,jóindulatú tervezés”-re van szükség, ahol a megfelelő szabályozás mellett kialakítanak olyan ösztönzőrendszert, amely esetében az üzleti érdekek elé helyezendő, jobb innovációs kultúra kialakítására, amely egyfajta új, szolgáltatásorientált üzleti modell is lehetne, tudatosítva a vállalkozói réteget, hogy például környezetbarátabb anyagokkal is lehet pénzt keresni, és ezen bevételi igények felé történő elmozdulás kívánatos.

Bár a társadalmi prioritások érezhetően átalakultak az ezredforduló környékén, egyre környezettudatosabbak az emberek, a társadalmi elfogadottság növelése tovább szükséges. Ez alatt nem csak az információátadás szükségességét érthetjük (pl. víz jelentősége, mennyisége, annak rendelkezésre állása a jövőben stb.) hanem például a társadalmi „teherviselés” szükségének, az esetleges közüzemi díjak emelésének elfogadását is.

\section{FELHASZNÁLT IRODALOM}

[1] KÜMMERER K.; DiOnYSIOU D.D.; OlsSON O.; FATTA-KASSINOS D.: A path to clean water; Science 20 Jul 2018; Vol. 361, Issue 6399, pp. 222-224

[2] DTE: Only 8 per cent of wastewater in low-income countries undergoes treatment; https://www.downtoearth.org.in/news/waste/only-8-per-cent-of-wastewater-in-lowincome-countries-undergoes-treatment-un-report-57732 (letöltve: 2019. január 30.)

[3] SCIENCE ORF: Europas Gewässer in schlechtem Zustand; https://science.orf.at/stories/2922470/ (letöltve: 2019. január 30.)

[4] IPCC: Special report on the impacts of global warming of $1.5{ }^{\circ} \mathrm{C}$; https://www.ipcc.ch/sr15/ (letöltve: 2018. december 29.)

[5] PADÁNYI J.: Vizkonfliktusok, Hadtudomány; A Magyar Hadtudományi Társaság folyóirata 25 (E-szám); pp. 272-284., 2015.

[6] NOVÁKY B.: Climatic effects on runoff conditions in Hungary. Special Issue on the landscape-ecological impact of climatic change. Earth Surface and Landforms, Vol. 16, No.7, pp. 593-600.1991.

[7] OPPERMAN J. J.; S. ORR; H BALETA; M.DAILEY; D. GARRICK; M. GOICHOT; A. MCCOY; A. MORGAN; L. TURLEY; A. VERMEULEN: Valuing Rivers: How the diverse benefits of healthy rivers underpin economies; WWF; ISBN:

978-2-940529-87-2; 2018. 
[8] HegedÜs H.: A Duna vizgyüjtő területének hazai szakasza az éghajlatváltozás tükrében, In: Berek Tamás; Csurgai József; Farkas Andrea; Földi László; Halász László; Hegedüs Hajnalka; Hornyacsek Júlia; Kohut László; Kuti Rajmund; Márton Andrea; Mika János; Mikulas Monosi; Restás Ágoston: Adaptációs lehetőségek az éghajlatváltozás következményeihez a közszolgálat területén BUDAPEST: Nemzeti Közszolgálati Egyetem, (2019) pp. 9-91., 83 p.,

[9] CSÖSZ L.: Die Problematik Der Abwasserreinigung Hinsichtlich Der Pharmazeutischen Substanzen Online: http://hadmernok.hu/184_11_csosz.pdf, (letöltve: 2018. november 19.)

[10] HegedÜs H.: Magyarország felszín alatti vizeinek fenntartható minőségvédelme a jogi szabályozás és a lehetséges javitó tevékenységek tükrében, $\mathrm{PhD}$ értekezés, NKE-KMDI, 2018, Online: $\quad$ https://www.uni-nke.hu/document/uni-nke-hu/HegedusHajnalka_Doktori-ertekezes_2018.pdf, (letöltve: 2018. december 30.)

[11] Barótfi I.: Környezettechnika, Mezőgazda Kiadó, ISBN 963923950 X 